\title{
Obesity Affects the Liver - The Link between Adipocytes and Hepatocytes
}

\author{
Alexander Wree Alisan Kahraman Guido Gerken Ali Canbay \\ Department of Gastroenterology and Hepatology, University of Duisburg-Essen, University Clinic Essen, \\ Essen, Germany
}

\section{Key Words}

Adipocyte $\cdot$ Lipoapoptosis $\cdot$ Nonalcoholic fatty liver disease $\cdot$ Obesity

\begin{abstract}
The incidence of obesity has dramatically increased in recent years. Consequently, obesity and associated disorders such as nonalcoholic fatty liver disease (NAFLD) constitute a serious threat. Therefore, the contribution of visceral adipose tissue to metabolic homeostasis has become a focus of interest. Visceral adipose tissue secretes free fatty acids (FFAs) and hormones, known as adipokines, and thus seems to play a major role in the development of NAFLD. Apoptotic cell death is a prominent feature in nonalcoholic steatohepatitis (NASH). Indeed, toxic FFAs can activate the intrinsic apoptosis pathway in hepatocytes via c-Jun N-terminal kinase (JNK). JNK activates the proapoptotic protein Bim, resulting in Bax activation and enhanced apoptosis, termed 'lipoapoptosis'. Reduced adiponectin levels may establish a proinflammatory milieu, thus increasing vulnerability to lipotoxicity, which promotes progression from simple steatosis to NASH and even advanced hepatic fibrosis. Moreover, obesity seems to be a risk factor for hepatocellular carcinoma, the most frequent liver cancer subtype. Even in acute liver failure, a high body mass index is associated with poor out-
\end{abstract}

come, and recent data suggest a major role of obesity in the progression of chronic hepatitis $C$ and $B$. This review summarizes current knowledge - highlighting the inflammatory and cytokine view - of the intimate relationship between adipose and liver tissue.

Copyright $\odot 2010$ S. Karger AG, Basel

\section{Introduction}

Obesity is a major issue worldwide and has increased dramatically during recent decades. Consequently, obesity and associated disorders now constitute a serious threat to the current and future health of all populations on earth. The World Health Organization (WHO) estimates that more than 1 billion adults worldwide are overweight, 300 million of whom are clinically obese - defined as having a body mass index (BMI) equal to or greater than $30 \mathrm{~kg} / \mathrm{m}^{2}$ [1]. Particularly alarming is the equally marked increase in obesity among children [2]. Obesity is associated with an array of additional health problems, including increased risk of insulin resistance (IR), type 2 diabetes, nonalcoholic fatty liver disease (NAFLD), atherosclerosis, degenerative disorders, including dementia, airway diseases, and even some cancers [3]. The clustering of abdominal obesity, IR, dyslip-

\section{KARGER}

Fax +41613061234 E-Mail karger@karger.ch www.karger.com

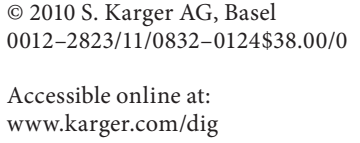

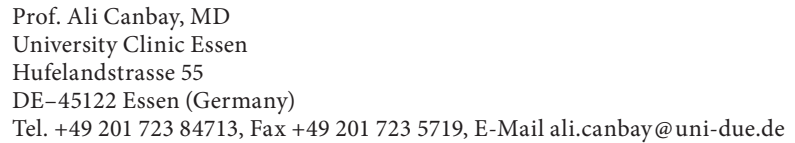




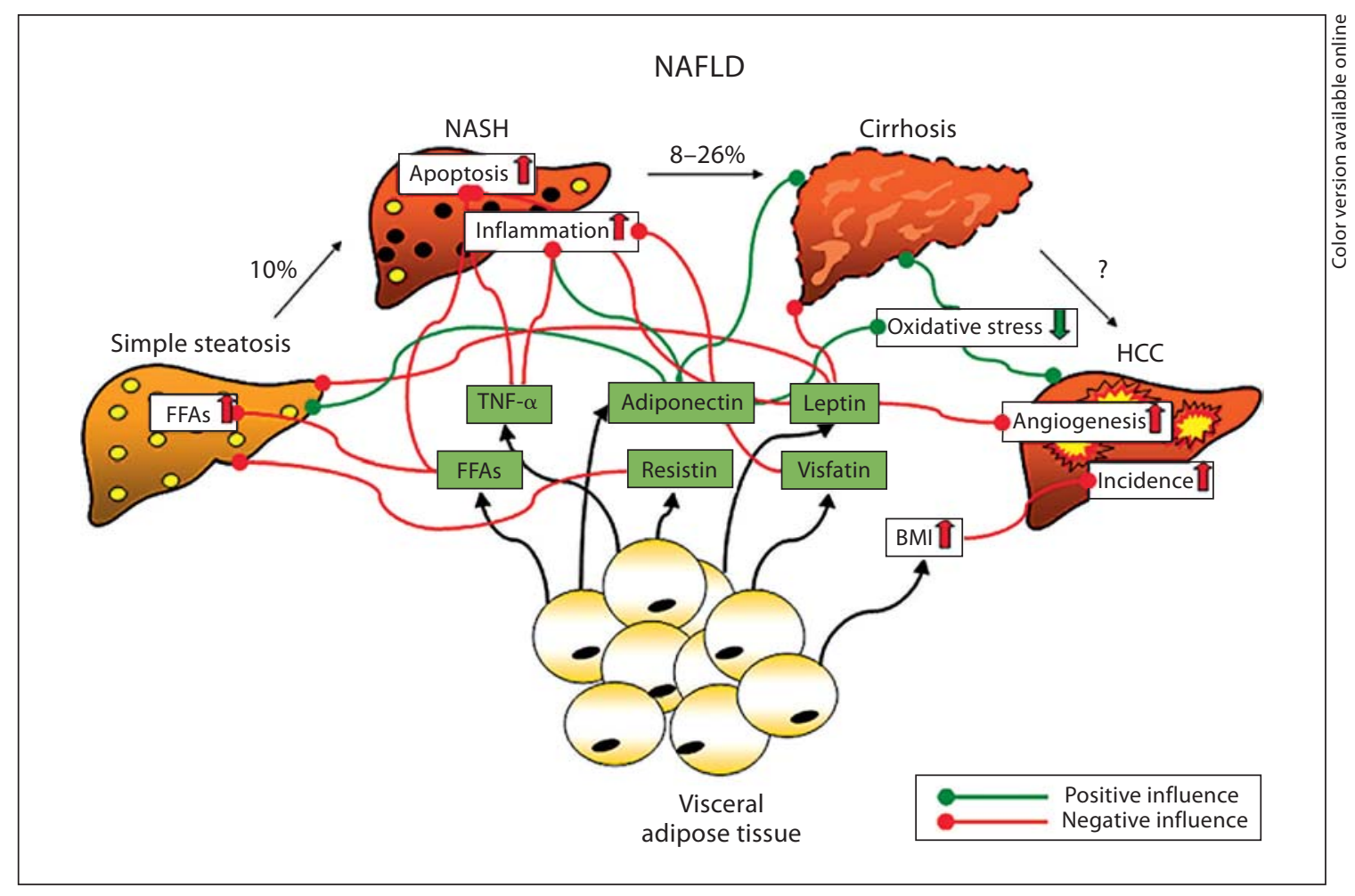

Fig. 1. Influence of visceral adipose tissue on NAFLD. Visceral adipose tissue secretes a variety of proteins, known as adipokines, which can influence the liver. FFAs play a major role in the development of simple steatosis. With the influence of adipokines like TNF- $\alpha$, simple steatosis can progress to NASH by induction of apoptosis and inflammation. Apart from adiponectin, which can prevent the development of NASH, cirrhosis and even HCC, most adipokines exert a negative influence on liver diseases. An elevated BMI may increase the incidence of many cancers, including HCC. idemia, and elevated blood pressure is known as the metabolic syndrome. Its components reflect overnutrition, sedentary life-styles, and resultant excess adiposity, which is associated with a chronic proinflammatory state. Unlike the hepatitis $\mathrm{C}$ virus (HCV) epidemic, which is estimated to peak in 2010, the obesity/metabolic syndrome epidemic shows no signs of abating [4].

The adipocyte and visceral adipose tissue have begun to fascinate researchers as a result of rapidly accumulating new knowledge of their function and contribution to whole-body metabolic homeostasis [5]. Three major functions of visceral adipose tissue have been characterized so far: (1) adipocytes have a large capacity to store energy in form of lipids; (2) lipids stored in adipocytes can be metabolized rapidly and either released as fatty acids (FAs) or used to increase thermogenesis by uncoupling substrate oxidation from ATP generation $[6,7]$, and (3) adipocytes communicate with other tissues by secreting hormones, commonly referred to as adipokines, in either an endocrine or a paracrine fashion [8].
The adipocyte secretome ranges from molecules of direct metabolic relevance to those with effects unrelated to metabolism. These include the adipocyte-specific proteins adiponectin and leptin, the inflammatory chemokine tumor necrosis factor- $\alpha$ (TNF- $\alpha$ ), and an array of interleukins, angiogenic, and vasoactive molecules such as vascular endothelial growth factor and angiotensinogen. Thus, visceral adipose tissue seems to play a major role by secreting free FAs (FFAs), hormones and adipokines, in the development of NAFLD and particularly in nonalcoholic steatohepatitis (NASH) (fig. 1). This article gives an overview of the current knowledge of the influence of obesity in liver diseases.

\section{Relation between the Liver and Adipose Tissue}

The intimate relationship between visceral adipose tissue and the liver reflects their common origins. Key metabolic and immune functions in higher organisms 
have evolved from common ancestral structures. One such structure is the Drosophila fat body, which incorporates the mammalian homologues of the liver and the hematopoietic and immune systems $[9,10]$. Interestingly, this site is also recognized as the equivalent of mammalian adipose tissue, sharing similar developmental and functional pathways $[11,12]$. The fly's fat body exerts a crucial function in sensing energy and nutrient availability and coordinates the appropriate metabolic and survival responses [9]. In higher organisms, the adipose tissue, the liver and the hematopoietic system have specialized into distinct functional units or organs. However, these organs have maintained their developmental heritage, which was shared in earlier organisms. Therefore, it is possible to imagine a situation in which common or overlapping pathways regulate both metabolic and immune functions through common key regulatory molecules and signaling systems.

It is remarkable to note that both visceral adipose tissue and the liver share similarities in which metabolic cells (adipocytes or hepatocytes) are in close proximity to e.g. immune cells (NK and NKT cells), Kupffer cells, hepatic stellate cells, and endothelial cells or macrophages, and both having immediate access to a vast network of blood vessels. With this configuration, both tissues form a suitable environment for continuous and dynamic interactions between immune and metabolic responses [13]. In fact, this interface might contribute to the emerging importance of these two organs in the initiation and development of metabolic diseases, particularly in the context of obesity and type 2 diabetes $[14,15]$.

\section{Obesity Is Highly Associated with NAFLD}

NAFLD is becoming the most common liver disease worldwide with approximately $30 \%$ of the population affected in industrialized, western countries. NAFLD is characterized by hepatic steatosis in the absence of a history of significant alcohol use or other known liver diseases. Alcohol intake as low as $20 \mathrm{~g}$ daily in women and $30 \mathrm{~g}$ daily in men may be sufficient to cause alcohol-induced liver disease [16]. In the general population of the Dionysos study, fatty liver at ultrasound examination was documented in $10-15 \%$ of normal individuals and in up to $76 \%$ of obese subjects not drinking alcohol in toxic amounts [17]. Compared with healthy controls, risk for steatosis was 4.6-fold increased in obese subjects and only 5.8 -fold higher in subjects who were obese and drank heavily.
Depending on etiologic factors, two different types of NAFLD can be distinguished - primary and secondary NAFLD [18]. Primary NAFLD emerges due to the metabolic syndrome. Secondary NAFLD is due to infections, medication intake, parenteral feeding, and rare metabolic and congenital diseases. Histopathologically, NAFLD can appear as simple steatosis (nonalcoholic fatty liver), or with inflammatory reaction defined as NASH with or without portal fibrosis that may lead to fatty liver-associated cirrhosis (NASH-induced cirrhosis). Approximately $10 \%$ of patients with NAFLD develop NASH and about $8-26 \%$ of individuals with NASH progress to cirrhosis [19]. These patients are at risk of developing hepatocellular cancer (HCC), portal hypertension with gastroesophageal bleeding, ascites and liver failure. Indeed, recent data implicate de novo HCC in NAFLD patients [20]. The pathogenesis of NAFLD and especially NASH is currently in the focus of many studies.

\section{FA Transport Proteins and the Development of Simple Steatosis (NAFL)}

FFAs play a pivotal role in the development of simple hepatic steatosis. The oral intake of fat and the subsequent lipolysis in visceral adipose tissue lead to an increased level of FFAs in the serum. Donnelly et al. [21] investigated the origin of FFAs and found that visceral adipose tissue was contributing $82 \%$ of the FFA pool in the fasting condition and $62 \%$ in the feeding condition. The lipid metabolism in the liver has 3 different aspects: (1) de novo synthesis and active uptake of FFAs; (2) processing via $\beta$-oxidation and/or de novo synthesis of triglycerides, and (3) export of FFAs as triglycerides and very low-density lipoproteins [22]. Several plasma membrane protein transporters are involved in the FA uptake process. The main translocation process across the plasma membrane involves members of the FA transporter protein (FATP) family. Indeed, when expressed, they facilitate the uptake of long-chain FA (C12-C20). FATPs are highly expressed in hepatocytes and adipocytes that reveal high-level FA uptake for both metabolism and storage. So far, six members of this protein family (FATP1-6) have been identified. Their isoforms show distinct organ-specific distribution patterns in human beings $[23,24]$. For example, FATP1 is found in visceral adipose tissue and in the heart. In contrast, FATP2 and FATP5 are expressed in the liver, while FATP4 is expressed in the intestine $[25,26]$. Indeed, overexpression of FATP5 in cultured cells has been shown to increase 
FFA uptake [23]. Recently, it has been shown that FATP5knockout mice exhibit less fat accumulation [23]. Thus, FATP5 is an important membrane protein involved in FA accumulation by the liver $[23,25]$. Indeed, we recently found a correlation between excess serum FFAs, hepatocyte apoptosis and fibrosis in patients with NAFLD. Moreover we showed that FATPs, in particular CD36/ FAT and FATP5, play an important role in the progression towards liver damage and failure in NASH [27].

\section{Adipokines Are Involved in the Development of NASH}

The combination of lipid accumulation in hepatocytes and apoptosis of hepatocytes is known as lipoapoptosis, which is a pivotal mechanism in NASH $[28,29]$. In hepatocytes, saturated FFAs (like palmitol or stearin acid) can induce a time- and dose-dependent lipoapoptosis [30]. These two toxic FFAs can activate the intrinsic pathway of apoptosis via c-Jun $\mathrm{N}$-terminal kinase (JNK). JNK activates the proapoptotic member of the Bcl-2 family Bim, resulting in activation of Bax and increased apoptosis. In line with this observation, a study by Schattenberg et al. [31] demonstrated that induction of JNK type 1 promotes the development of NASH.

Visceral adipose tissue may affect the development of NASH by secreting TNF- $\alpha$, which is highly expressed in the metabolic syndrome [13]. Clinically enhanced TNF$\alpha$ expression was shown in patients with NASH compared with patients exhibiting simple steatosis [32]. Experimental data described that FFAs induced TNF- $\alpha$ production through promoting hepatic lipotoxicity [33]. In turn, TNF- $\alpha$ activates nuclear factor $\kappa \mathrm{B}$ via TNF-receptor 1 (TNF-R1) as a central transcription factor for many proinflammatory cytokines [33]. TNF- $\alpha$ further induces de novo lipogenesis in hepatocytes, leading to lipid accumulation. In case of TNF- $\alpha$ signal-chain interruption - either pharmacologic or genetic -, reduced lipid accumulation can be documented [34, 35]. Taken together, these findings indicate that TNF- $\alpha$ is one of the critical factors for occurrence and progression of NAFLD/ NASH.

While results from controlled animal experiments seemed quite clear, circulating levels of leptin in patients with NAFLD provided rather ambiguous data. With advancing stages of liver disease, higher levels of circulating leptin were found although the concentration was independent of BMI in NASH patients [36]. On the other hand, serum leptin was correlated with severity of steato- sis but not with inflammation or liver fibrosis [37]. In contrast to this, some studies revealed no significant differences in leptin serum concentration of NASH patients compared with healthy controls [16, 38]. Strong evidence was provided that leptin acts as a fibrogenic agent in animal models, but complementary data in patients are ambiguous or missing. Further studies may clarify the role of leptin in humans, especially regarding its influence on liver tissue.

Adiponectin is thought to counteract IR and to have protective effects. Despite this, NASH patients exhibit reduced adiponectin levels compared with matched controls or patients with simple steatosis, seemingly without any relation to IR or the waist-hip ratio [39]. While low adiponectin was associated only with increased steatosis and necroinflammation, IR additionally predicted severe hepatic fibrosis. Other studies demonstrated a correlation between adiponectin levels and suppression of endogenous glucose, as well as an inverse association of adiponectin with intrahepatic fat. Adiponectin levels also predicted the presence of the metabolic syndrome but not inflammation or fibrosis [40]. The correlation of adiponectin with hepatic fat content, IR and altered lipid metabolism has been described in other studies investigating nondiabetic subjects $[41,42]$. Taking all data together, adiponectin levels generally predict steatosis and severity of liver disease although to what extent this is a direct effect or related to the presence of more severe IR remains to be addressed. Nevertheless, reduced levels of adiponectin in obesity and IR establish a proinflammatory milieu and individual susceptibility to lipotoxicity could determine which subjects ultimately progress from simple steatosis to NASH and develop advanced hepatic fibrosis. Indeed, Xu et al. [43] demonstrated that adiponectin administration significantly improved fatty liver in mice. Moreover, in adiponectin knockout mice, liver injury and fibrosis were increased [44].

Resistin - another adipokine - varied between different studies in NAFLD patients. On the one hand, raised mRNA expression of resistin in visceral adipose tissue and raised plasma levels of resistin were found in one group of patients with NAFLD and NASH compared with lean and obese control groups [45]. Other investigators reported decreased resistin concentrations in NAFLD patients. Low resistin was negatively correlated with intrahepatic fat content, although this did not reach statistical significance [46]. A third study demonstrated unaltered resistin expression in visceral adipose tissue of patients undergoing bariatric surgery while serum resistin was increased in NASH patients with IR [47]. Interestingly, re- 
Table 1. Serum levels of different adipokines in liver diseases

\begin{tabular}{lllllll}
\hline & Adiponectin & FFAs & TNF- $\alpha$ & Leptin & Resistin & Visfatin \\
\hline Lean & $\leftrightarrow$ & $\leftrightarrow$ & $\leftrightarrow$ & $\leftrightarrow$ & $\leftrightarrow$ & $\leftrightarrow$ \\
Obese & $\downarrow$ & $\uparrow$ & $\uparrow$ & $\uparrow$ & $\uparrow$ & $\uparrow$ \\
Simple steatosis & $\downarrow$ & $\uparrow$ & $\uparrow$ & $\leftrightarrow / \uparrow^{*}$ & $\uparrow$ & $\uparrow \uparrow$ \\
NASH & $\downarrow$ & $\uparrow$ & $\uparrow$ & $\leftrightarrow / \uparrow^{*}$ & $\uparrow \uparrow$ & $\uparrow$ \\
ALF & $\uparrow$ & 0 & 0 & 0 & 0 & 0 \\
Liver cirrhosis & $\downarrow$ & 0 & 0 & $\uparrow$ & $\downarrow$ & $\downarrow$ \\
CHC & $\uparrow / \downarrow^{*}$ & 0 & 0 & $\leftrightarrow / \uparrow^{*}$ & $\uparrow$ & 0 \\
\hline
\end{tabular}

* = Conflicting data available; $0=$ no data available; $\leftrightarrow=$ normal; $\downarrow=$ reduced; $\downarrow \downarrow=$ strongly reduced; $\uparrow=\mathrm{el}$ evated; $\uparrow \uparrow=$ strongly elevated; NASH $=$ non-alcoholic steatohepatitis; ALF = acute liver failure; $\mathrm{CHC}=\mathrm{chronic}$ hepatitis $\mathrm{C}$ virus infection.

sistin expression in liver tissue of patients suffering from alcohol-induced liver disease or NASH was increased and correlated with inflammatory cell infiltration [48].

Studies investigating other adipokines like visfatin with regard to NAFLD are rare. NASH patients exhibited lower visfatin levels than those with simple steatosis or obese controls although, compared with healthy controls, all groups of obese patients had increased visfatin [49]. Additionally, elevation of visfatin levels predicted portal inflammation [50].

Information of the biological basis of adipokine action in the context of liver diseases is given by an excellent review by Marra and Bertolani [51]. Information on other adipokines may be found in another recent review [52].

Though the role of some adipokines remains unclear and ambiguous, obesity and especially adipokines as crucial mediators directly influence hepatic steatosis, steatohepatitis, and NASH-induced cirrhosis (table 1).

\section{Obesity Is a Risk Factor for HCC}

Obesity is a risk factor for several chronic diseases, most notably hypertension, type 2 diabetes, dyslipidemia, and chronic heart diseases. In addition, obesity has been shown to constitute a risk factor for colon cancer, postmenopausal breast cancer, endometrial cancer, renal cell cancer, as well as adenocarcinoma of the esophagus [53].

HCC is the most rapidly increasing cause of cancer death in the United States and Europe. From 1973 to 1980 intrahepatic liver cancers ranked as the 8th most common malignancy in the United States, accounting for 1 death per 100,000. In 1998, intrahepatic liver cancer ranked as the 6th most common malignancy, resulting in a death rate of 3.5 per 100,000 [54]. Although many risk factors for HCC are well defined, including hepatitis B/C viruses and alcohol, most series have indicated that $5-30 \%$ of patients with HCC lack a readily identifiable risk factor for their cancer [55]. Obesity and type 2 diabetes are also likely to be risk factors for HCC, the most frequent subtype of liver cancer [56]. Interestingly, most cases of 'cryptogenic' HCC in the United States are attributed to NAFLD [57]. The main pathway by which obesity increases risk probability relates to the association between obesity and NAFLD [58]. Retrospective data suggest that after cirrhosis has developed, $4-27 \%$ of cases of NASH transform to HCC [59]. These figures lead to theoretical HCC incidence rates ranging from 0.6 to 210 per 100,000 . Case reports have also described patients with $\mathrm{NASH}$ who developed HCC without underlying cirrhosis [60, 61]. Additionally, animal models have demonstrated a clear progression from NASH to cirrhosis and to cancer [62]. Although, in a smaller patient cohort, obesity significantly increased HCC [63], a larger study including 1,145 patients failed to reproduce these findings [64]. Large prospective studies are needed to further address both of these issues more definitively.

Comorbidities, such as coronary artery disease and/or worsened secondary effects of chemotherapy, in obese individuals may be responsible for an impaired outcome although the general relations remain ambiguous [65]. Another study found that visceral adipose tissue is able to secrete vascular endothelial growth factor and other adipokines, suggesting dysregulated angiogenesis as a possible connection between obesity and worsened clinical outcome [66]. In animal models, leptin has been shown to promote angiogenesis and thus could facilitate progression of NASH to HCC [67]. In addition, leptin is 
able to activate multiple signal transduction pathways, such as JNK, protein kinase B, the AKT pathway, and the extracellular signal-regulated kinase pathway in HCC cells, all recognized to promote cancer progression [68].

Little information is available on the role of adiponectin in liver cancer although administration of a cholineand amino acid-deficient diet to adiponectin-knockout mice has recently resulted in an increased incidence of liver tumors [69]. These correlations suggest a possible association between the metabolic syndrome and worsened clinical outcomes that may be related to adipokines.

\section{Obesity Is a Negative Prognostic Factor in the Treatment of Chronic Hepatitis C}

Obesity is recognized as a cofactor in liver injury induced by chronic hepatitis $\mathrm{C}$ (CHC) infection. Adipokines may be the link between increased $\mathrm{BMI}$ and disease progression in CHC. For example, $\mathrm{CHC}$ genotype 3 infection is likely to produce steatosis through a virus-mediated mechanism [70]. In subjects with genotype non-3 $\mathrm{CHC}$ infection, steatosis is generally considered as the effect of coexisting metabolic conditions [71], possibly exacerbated by viral infection [72]. The presence of obesity and obesity-associated IR and steatosis facilitates the development of diabetes in the precirrhotic stage, carries a higher risk of failure during interferon treatment [73] or higher recurrence after initial response [74], and increases fibrosis [75-77].

In a meta-analysis on data from 3,068 patients with histologically confirmed $\mathrm{CHC}$ recruited by 10 clinical centers in different ethnic settings, steatosis was independently associated with several variables, including higher BMI and predicted hepatic fibrosis [78]. On this basis, pretreatments of IR with insulin-sensitizing agents and/or weight loss by dietary intervention have been proposed as preinterferon strategies to increase sustained virological response [74]. In addition, adiponectin has recently been shown to protect against Fas-mediated hepatocyte death, with possible implications for patients with CHC [79].

Obesity, steatosis, and IR have a negative impact on disease progression and response to antiviral therapy in patients with $\mathrm{CHC}$ [80]. Treatment failure in obese patients might result from lower interferon concentrations and a milder biological response upon exposure to exogenous interferon- $\alpha$ in obese patients [81]. In turn, $\mathrm{CHC}$ is often associated with alterations in glucose metabolism, leading to hepatic steatosis, IR, and type 2 diabetes [82]. Fatty liver is generally more evident in patients infected with HCV genotype 3, where virus-specific mechanisms play a pivotal role (so-called 'viral steatosis'). In contrast, 'metabolic steatosis' is associated with HCV genotypes other than genotype 3 , with host factors playing a major pathogenic role.

Regarding IR, steatosis, and liver injury in $\mathrm{CHC}$, impact and regulation of leptin is as ambiguous as in NAFLD. Leptin was shown to be increased in CHC-infected patients compared with healthy controls [83]. In contrast, other studies found similar or even lower concentrations of leptin in such patients $[36,84,85]$. Likewise, some groups observed a positive correlation between leptin and the severity of fibrosis $[86,87]$ while other groups did not $[84,88]$. If leptin has an impact on $\mathrm{CHC}$-induced steatosis this has to be further elucidated since leptin levels were associated with steatosis [88] or correlated with steatosis in patients infected with genotype 1 but not with genotype 3 [89]. Conversely, other studies could not show any alteration of serum leptin levels in the context of steatosis $[84,86]$.

In contrast to NAFLD, serum adiponectin levels in CHC patients were not consistently different from those of healthy subjects, even after matching for age, gender, and BMI [90-92]. Whereas one study associated high viral load and genotype 2 infection with decreased serum adiponectin [90], another group did not find any relation between histological features and concentrations of adiponectin, leptin or IL-6 levels in serum [93]. Thus, virusrelated effects, independent of adipokines may lead to the more severe IR observed in patients with $\mathrm{CHC}$. While one study demonstrated hepatic steatosis to be associated with decreased adiponectin levels [94], a different group found this relation only in males [95]. Additionally, CHC patients exhibit an interrelation between hypoadiponectinemia and the grade of hepatic steatosis in $\mathrm{CHC}$, suggesting a pathogenetic mechanism involving dysregulation of adiponectin and TNF- $\alpha$ levels [96]. Independently of steatosis, lower adiponectin levels were detected in patients with genotype $3[96,97]$, which increased after successful antiviral treatment, implying a direct effect of the virus on adiponectin [98]. This is also supported by nonresponders to antiviral therapy showing low adiponectin levels [98]. Combined CHC infection and steatosis increase hepatocyte expression of CD95/Fas, making the cells more susceptible to apoptotic stimuli, which again amplifies inflammation and fibrosis [79].

In contrast to NAFLD, no other adipokines have been scrutinized in CHC. Serum resistin, for example, is increased in $\mathrm{CHC}$ compared with NASH patients, but was inversely related to fibrosis stage [99]. 


\section{Obesity Is Associated with Poor Outcome in Acute Liver Failure}

Acute liver failure (ALF) is a devastating clinical syndrome associated with high mortality [100]. Annually, approximately $8 \%$ of all current liver transplantations in Europe are required as a result of ALF. Several studies have recently demonstrated that a high BMI is associated with a preexisting liver damage. Such damage can manifest as steatosis and obviously corresponds to an increasingly poor outcome in patients with ALF $[101,102]$. These results must be viewed as preliminary as both studies were conducted for limited periods of time and on small numbers of patients only. An attempt to obtain prospective data over a longer period of time and from a larger cohort of patients therefore promises to provide more reliable information about conditions associated with the onset and outcome of ALF.

Multivariate analyses in patients without preexisting liver damage (for example NAFLD) did not identify BMI as an independent predictor [103]. Preexisting liver damage due to obesity renders subjects more susceptible to a 'second hit' (such as by drug toxicity or viral hepatitis), which results in acute-on-chronic liver failure [101, 102, 104]; this is in line with findings from overweight rodents. Therefore, obesity should be considered as a relevant prognostic factor in patients with ALF [103].

\section{Conclusion}

Obesity and visceral adipose tissue affect the liver and hepatocytes. The liver disease influenced most by obesity is NAFLD. It is well established that the development of NAFLD is closely linked to an excess flow of FFAs arising from visceral adipose tissue. Chronic lipid supply exceeding the metabolic ability of the liver may induce hepatocellular injury. Multiple mechanisms including proinflammatory cytokines and pathways have been implicated in the pathogenesis of NAFLD. Understanding the role of obesity and lipotoxicity in patients with liver disease as part of a broader metabolic disorder is likely to improve the management of these challenging diseases. In CHC, studies have shown that HCV core proteins can directly inhibit insulin signaling, leading to poor outcomes. However, the mechanisms by which obesity and visceral adipose tissue affect cancer development remain to be elucidated.

\section{Acknowledgment}

We would like to thank Jan-Peter Sowa for critically reviewing the manuscript.

\section{References}

1 WHO: The World Health Report 2002 - Reducing Risks, Promoting Healthy Life 2009; Available from: http://www.who.int/whr/ 2002/en/.

$\checkmark 2$ Rocchini AP: Childhood obesity and a diabetes epidemic. N Engl J Med 2002;346:854855.

-3 Semenkovich CF: Insulin resistance and atherosclerosis. J Clin Invest 2006;116:18131822 .

4 Wong JB, McQuillan GM, McHutchison JG, Poynard T: Estimating future hepatitis C morbidity, mortality, and costs in the United States. Am J Public Health 2000;90:15621569.

$\checkmark 5$ Klein J, Perwitz N, Kraus D, Fasshauer M: Adipose tissue as source and target for novel therapies. Trends Endocrinol Metab 2006; 17:26-32.

-6 Lafontan M: Fat cells: afferent and efferent messages define new approaches to treat obesity. Annu Rev Pharmacol Toxicol 2005; 45:119-146.
7 Klaus S: Adipose tissue as a regulator of energy balance. Curr Drug Targets 2004;5: 241-250. Kershaw EE, Flier JS: Adipose tissue as an endocrine organ. J Clin Endocrinol Metab 2004;89:2548-2556.

$\checkmark 9$ Søndergaard L: Homology between the mammalian liver and the Drosophila fat body. Trends Genet 1993;9:193.

$>10$ Leclerc V, Reichhart J: The immune response of Drosophila melanogaster. Immunol Rev 2004;198:59-71.

11 Tong Q, Dalgin G, Xu H, Ting CN, Leiden JM, Hotamisligil GS: Function of GATA transcription factors in preadipocyte-adipocyte transition. Science 2000;290:134-138

12 Rusten TE, Lindmo K, Juhász G, Sass M, Seglen PO, Brech A, Stenmark H: Programmed autophagy in the Drosophila fat body is induced by ecdysone through regulation of the PI3K pathway. Dev Cell 2004;7: 179-192.

13 Hotamisligil GS: Inflammation and metabolic disorders. Nature 2006;444:860-867.
14 Wellen KE, Hotamisligil GS: Inflammation, stress, and diabetes. J Clin Invest 2005;115: 1111-1119.

15 Shoelson SE, Lee J, Goldfine AB: Inflammation and insulin resistance. J Clin Invest 2006;116:1793-1801.

16 Angulo P, Alba LM, Petrovic LM, Adams LA, Lindor KD, Jensen MD: Leptin, insulin resistance, and liver fibrosis in human nonalcoholic fatty liver disease. J. Hepatol 2004;41: 943-949.

$>17$ Bedogni G, Miglioli L, Masutti F, Tiribelli C, Marchesini G, Bellentani S: Prevalence of and risk factors for nonalcoholic fatty liver disease: the Dionysos Nutrition and Liver study. Hepatology 2005;42:44-52.

18 Lazo M, Clark JM: The epidemiology of nonalcoholic fatty liver disease: a global perspective. Semin Liver Dis 2008;28:339-350.

$>19$ Matteoni CA, Younossi ZM, Gramlich T, Boparai N, Liu YC, McCullough AJ: Nonalcoholic fatty liver disease: a spectrum of clinical and pathological severity. Gastroenterology 1999;116:1413-1419. 
-20 Guzman G, Brunt EM, Petrovic LM, Chejfec G, Layden TJ, Cotler SJ: Does nonalcoholic fatty liver disease predispose patients to hepatocellular carcinoma in the absence of cirrhosis? Arch Pathol Lab Med 2008;132:17611766.

21 Donnelly KL, Smith CI, Schwarzenberg SJ, Jessurun J, Boldt MD, Parks EJ: Sources of fatty acids stored in liver and secreted via lipoproteins in patients with nonalcoholic fatty liver disease. J Clin Invest 2005;115:13431351.

22 Canbay A, Bechmann L, Gerken G: Lipid metabolism in the liver. $\mathrm{Z}$ Gastroenterol 2007;45:35-41.

>23 Ehehalt R, Füllekrug J, Pohl J, Ring A, Herrmann T, Stremmel W: Translocation of long chain fatty acids across the plasma membrane - lipid rafts and fatty acid transport proteins. Mol Cell Biochem 2006;284:135140.

24 Frohnert BI, Bernlohr DA: Regulation of fatty acid transporters in mammalian cells. Prog Lipid Res 2000;39:83-107.

25 Pohl J, Ring A, Hermann T, Stremmel W: Role of FATP in parenchymal cell fatty acid uptake. Biochim Biophys Acta 2004;1686: 1-6.

-26 Stahl A, Gimeno RE, Tartaglia LA, Lodish HF: Fatty acid transport proteins: a current view of a growing family. Trends Endocrinol Metab 2001;12:266-273.

27 Bechmann LP, Gieseler RK, Sowa J, Kahraman A, Erhard J, Wedemeyer I, Emons B, Jochum C, Feldkamp T, Gerken G, Canbay A: Apoptosis is associated with CD36/ fatty acid translocase upregulation in nonalcoholic steatohepatitis. Liver Int 2010; Available from: http://www.ncbi.nlm.nih. gov/pubmed/20408954.

-28 Feldstein AE, Canbay A, Angulo P, Taniai M, Burgart LJ, Lindor KD, Gores GJ: Hepatocyte apoptosis and fas expression are prominent features of human nonalcoholic steatohepatitis. Gastroenterology 2003;125:437-443

-29 Malhi H, Gores GJ: Molecular mechanisms of lipotoxicity in nonalcoholic fatty liver disease. Semin Liver Dis 2008;28:360-369.

-30 Malhi H, Barreyro FJ, Isomoto H, Bronk SF, Gores GJ: Free fatty acids sensitise hepatocytes to TRAIL mediated cytotoxicity. Gut 2007;56:1124-1131.

-31 Schattenberg JM, Singh R, Wang Y, Lefkowitch JH, Rigoli RM, Scherer PE, Czaja MJ: JNK1 but not JNK2 promotes the development of steatohepatitis in mice. Hepatology 2006;43:163-172.

>32 Crespo J, Cayón A, Fernández-Gil P, Hernández-Guerra M, Mayorga M, DomínguezDíez A, Fernández-Escalante JC, PonsRomero F: Gene expression of tumor necrosis factor- $\alpha$ and TNF-receptors, p55 and p75, in nonalcoholic steatohepatitis patients. Hepatology 2001;34:1158-1163.
33 Feldstein AE, Werneburg NW, Canbay A, Guicciardi ME, Bronk SF, Rydzewski R, Burgart LJ, Gores GJ: Free fatty acids promote hepatic lipotoxicity by stimulating TNF- $\alpha$ expression via a lysosomal pathway. Hepatology 2004;40:185-194

34 Barbuio R, Milanski M, Bertolo MB, Saad MJ, Velloso LA: Infliximab reverses steatosis and improves insulin signal transduction in liver of rats fed a high-fat diet. J Endocrinol 2007; 194:539-550.

35 Solomon SS, Usdan LS, Palazzolo MR: Mechanisms involved in tumor necrosis factor- $\alpha$ induction of insulin resistance and its reversal by thiazolidinedione(s). Am J Med Sci 2001;322:75-78.

36 Uygun A, Kadayifci A, Yesilova Z, Erdil A, Yaman H, Saka M, Deveci MS, Bagci S, Gulsen M, Karaeren N, Dagalp K: Serum leptin levels in patients with nonalcoholic steatohepatitis. Am J Gastroenterol 2000;95: 3584-3589.

-37 Chitturi S, Farrell G, Frost L, Kriketos A, Lin R, Fung C, Liddle C, Samarasinghe D, George J: Serum leptin in NASH correlates with hepatic steatosis but not fibrosis: a manifestation of lipotoxicity? Hepatology 2002; 36:403-409.

38 Chalasani N, Crabb DW, Cummings OW, Kwo PY, Asghar A, Pandya PK, Considine RV: Does leptin play a role in the pathogenesis of human nonalcoholic steatohepatitis? Am J Gastroenterol 2003;98:2771-2776.

-39 Hui JM, Hodge A, Farrell GC, Kench JG, Kriketos A, George J: Beyond insulin resistance in NASH: TNF- $\alpha$ or adiponectin? Hepatology 2004;40:46-54.

-40 Bugianesi E, Pagotto U, Manini R, Vanni E, Gastaldelli A, de Iasio R, Gentilcore E, Natale S, Cassader M, Rizzetto M, Pasquali R, Marchesini G: Plasma adiponectin in nonalcoholic fatty liver is related to hepatic insulin resistance and hepatic fat content, not to liver disease severity. J Clin Endocrinol Metab 2005;90:3498-3504.

41 Westerbacka J, Cornér A, Tiikkainen M, Tamminen M, Vehkavaara S, Häkkinen A, Fredriksson J, Yki-Järvinen $\mathrm{H}$ : Women and men have similar amounts of liver and intraabdominal fat, despite more subcutaneous fat in women: implications for sex differences in markers of cardiovascular risk. Diabetologia 2004;47:1360-1369.

42 Matikainen N, Mänttäri S, Westerbacka J, Vehkavaara S, Lundbom N, Yki-Järvinen H, Taskinen M: Postprandial lipemia associates with liver fat content. J Clin Endocrinol Metab 2007;92:3052-3059.

43 Xu A, Wang Y, Keshaw H, Xu LY, Lam KSL, Cooper GJS: The fat-derived hormone adiponectin alleviates alcoholic and nonalcoholic fatty liver diseases in mice. J Clin Invest 2003;112:91-100.
44 Kamada Y, Tamura S, Kiso S, Matsumoto H, Saji Y, Yoshida Y, Fukui K, Maeda N, Nishizawa H, Nagaretani H, Okamoto Y, Kihara S, Miyagawa J, Shinomura Y, Funahashi T, Matsuzawa Y: Enhanced carbon tetrachloride-induced liver fibrosis in mice lacking adiponectin. Gastroenterology 2003;125: 1796-1807.

45 Pagano C, Soardo G, Pilon C, Milocco C, Basan L, Milan G, Donnini D, Faggian D, Mussap M, Plebani M, Avellini C, Federspil G, Sechi LA, Vettor R: Increased serum resistin in nonalcoholic fatty liver disease is related to liver disease severity and not to insulin resistance. J Clin Endocrinol Metab 2006;91: 1081-1086.

46 Perseghin G, Bonfanti R, Magni S, Lattuada G, De Cobelli F, Canu T, Esposito A, Scifo P, Ntali G, Costantino F, Bosio L, Ragogna F, Del Maschio A, Chiumello G, Luzi L: Insulin resistance and whole body energy homeostasis in obese adolescents with fatty liver disease. Am J Physiol Endocrinol Metab 2006; 291:E697-E703

47 Baranova A, Gowder SJ, Schlauch K, Elariny $\mathrm{H}$, Collantes R, Afendy A, Ong JP, Goodman Z, Chandhoke V, Younossi ZM: Gene expression of leptin, resistin, and adiponectin in the white adipose tissue of obese patients with non-alcoholic fatty liver disease and insulin resistance. Obes Surg 2006;16:11181125.

48 Bertolani C, Sancho-Bru P, Failli P, Bataller R, Aleffi S, DeFranco R, Mazzinghi B, Romagnani P, Milani S, Ginés P, Colmenero J, Parola M, Gelmini S, Tarquini R, Laffi G, Pinzani M, Marra F: Resistin as an intrahepatic cytokine: overexpression during chronic injury and induction of proinflammatory actions in hepatic stellate cells. Am J Pathol 2006; 169:2042-2053.

-49 Jarrar MH, Baranova A, Collantes R, Ranard B, Stepanova M, Bennett C, Fang Y, Elariny H, Goodman Z, Chandhoke V, Younossi ZM: Adipokines and cytokines in non-alcoholic fatty liver disease. Aliment Pharmacol Ther 2008;27:412-421.

50 Aller R, de Luis DA, Izaola O, Sagrado MG, Conde R, Velasco MC, Alvarez T, Pacheco D, González JM: Influence of visfatin on histopathological changes of non-alcoholic fatty liver disease. Dig Dis Sci 2009;54:1772-1777.

-51 Marra F, Bertolani C: Adipokines in liver diseases. Hepatology 2009;50:957-969.

52 Rabe K, Lehrke M, Parhofer KG, Broedl UC: Adipokines and insulin resistance. Mol Med 2008;14:741-751.

-53 Pischon T, Nöthlings U, Boeing H: Obesity and cancer. Proc Nutr Soc 2008;67:128-145.

54 Howe HL, Wingo PA, Thun MJ, Ries LA, Rosenberg HM, Feigal EG, Edwards BK: Annual report to the nation on the status of cancer (1973 through 1998), featuring cancers with recent increasing trends. J Natl Cancer Inst 2001;93:824-842. 
-55 Caldwell SH, Oelsner DH, Iezzoni JC, Hespenheide EE, Battle EH, Driscoll CJ: Cryptogenic cirrhosis: clinical characterization and risk factors for underlying disease. Hepatology 1999;29:664-669.

-56 Caldwell SH, Crespo DM, Kang HS, AlOsaimi AMS: Obesity and hepatocellular carcinoma. Gastroenterology 2004;127:S97S103.

57 Adams LA, Lindor KD: Nonalcoholic fatty liver disease. Ann Epidemiol 2007;17:863869.

58 Clark JM: The epidemiology of nonalcoholic fatty liver disease in adults. J Clin Gastroenterol 2006;40(suppl 1):S5-S10.

59 Ratziu V, Bonyhay L, Di Martino V, Charlotte F, Cavallaro L, Sayegh-Tainturier M, Giral P, Grimaldi A, Opolon P, Poynard T: Survival, liver failure, and hepatocellular carcinoma in obesity-related cryptogenic cirrhosis. Hepatology 2002;35:1485-1493.

-60 Powell EE, Cooksley WG, Hanson R, Searle J, Halliday JW, Powell LW: The natural history of nonalcoholic steatohepatitis: a follow-up study of forty-two patients for up to 21 years. Hepatology 1990;11:74-80.

61 Cotrim HP, Paraná R, Braga E, Lyra L: Nonalcoholic steatohepatitis and hepatocellular carcinoma: natural history? Am J Gastroenterol 2000;95:3018-3019.

62 de Lima VMR, Oliveira CPMS, Alves VAF, Chammas MC, Oliveira EP, Stefano JT, de Mello ES, Cerri GG, Carrilho FJ, Caldwell $\mathrm{SH}$ : A rodent model of NASH with cirrhosis, oval cell proliferation and hepatocellular carcinoma. J Hepatol 2008;49:1055-1061.

63 Calle EE, Rodriguez C, Walker-Thurmond $\mathrm{K}$, Thun MJ: Overweight, obesity, and mortality from cancer in a prospectively studied cohort of US adults. N Engl J Med 2003;348: 1625-1638.

64 Park SM, Lim MK, Shin SA, Yun YH: Impact of prediagnosis smoking, alcohol, obesity, and insulin resistance on survival in male cancer patients: National Health Insurance Corporation Study. J Clin Oncol 2006;24: 5017-5024.

65 Griggs JJ, Sorbero MES, Lyman GH: Undertreatment of obese women receiving breast cancer chemotherapy. Arch Intern Med 2005; 165:1267-1273.

-66 Rega G, Kaun C, Demyanets S, Pfaffenberger S, Rychli K, Hohensinner PJ, Kastl SP, Speidl WS, Weiss TW, Breuss JM, Furnkranz A, Uhrin P, Zaujec J, Zilberfarb V, Frey M, Roehle R, Maurer G, Huber K, Wojta J: Vascular endothelial growth factor is induced by the inflammatory cytokines interleukin- 6 and oncostatin $\mathrm{m}$ in human adipose tissue in vitro and in murine adipose tissue in vivo. Arterioscler Thromb Vasc Biol 2007;27: 1587-1595.
67 Ikejima K, Takei Y, Honda H, Hirose M, Yoshikawa M, Zhang Y, Lang T, Fukuda T, Yamashina S, Kitamura T, Sato N: Leptin receptor-mediated signaling regulates hepatic fibrogenesis and remodeling of extracellular matrix in the rat. Gastroenterology 2002; 122:1399-1410.

68 Saxena NK, Sharma D, Ding X, Lin S, Marra F, Merlin D, Anania FA: Concomitant activation of the JAK/STAT, PI3K/AKT, and ERK signaling is involved in leptin-mediated promotion of invasion and migration of hepatocellular carcinoma cells. Cancer Res 2007;67:2497-2507.

69 Kamada Y, Matsumoto H, Tamura S, Fukushima J, Kiso S, Fukui K, Igura T, Maeda N, Kihara S, Funahashi T, Matsuzawa Y, Shimomura I, Hayashi N: Hypoadiponectinemia accelerates hepatic tumor formation in a nonalcoholic steatohepatitis mouse model. J Hepatol 2007;47:556-564.

70 Rubbia-Brandt L, Fabris P, Paganin S, Leandro G, Male P, Giostra E, Carlotto A, Bozzola L, Smedile A, Negro F: Steatosis affects chronic hepatitis $\mathrm{C}$ progression in a genotype specific way. Gut 2004;53:406-412

71 Monto A, Alonzo J, Watson JJ, Grunfeld C, Wright TL: Steatosis in chronic hepatitis C: relative contributions of obesity, diabetes mellitus, and alcohol. Hepatology 2002;36: 729-736.

72 Negro F: Hepatitis C virus and liver steatosis: is it the virus? Yes it is, but not always. Hepatology 2002;36:1050-1052.

73 Bressler BL, Guindi M, Tomlinson G, Heathcote J: High body mass index is an independent risk factor for nonresponse to antiviral treatment in chronic hepatitis C. Hepatology 2003;38:639-644.

74 Romero-Gómez M, Del Mar Viloria M, Andrade RJ, Salmerón J, Diago M, FernándezRodríguez CM, Corpas R, Cruz M, Grande L, Vázquez L, Muñoz-De-Rueda P, LópezSerrano P, Gila A, Gutiérrez ML, Pérez C, Ruiz-Extremera A, Suárez E, Castillo J: Insulin resistance impairs sustained response rate to peginterferon plus ribavirin in chronic hepatitis C patients. Gastroenterology 2005;128:636-641.

75 Adinolfi LE, Utili R, Ruggiero G: Body composition and hepatic steatosis as precursors of fibrosis in chronic hepatitis $\mathrm{C}$ patients. Hepatology 1999;30:1530-1531

76 Hourigan LF, Macdonald GA, Purdie D, Whitehall VH, Shorthouse C, Clouston A, Powell EE: Fibrosis in chronic hepatitis $\mathrm{C}$ correlates significantly with body mass index and steatosis. Hepatology 1999;29:12151219.

77 Castéra L, Hézode C, Roudot-Thoraval F, Bastie A, Zafrani E, Pawlotsky J, Dhumeaux D: Worsening of steatosis is an independent factor of fibrosis progression in untreated patients with chronic hepatitis $\mathrm{C}$ and paired liver biopsies. Gut 2003;52:288-292.
78 Leandro G, Mangia A, Hui J, Fabris P, Rubbia-Brandt L, Colloredo G, Adinolfi LE, Asselah T, Jonsson JR, Smedile A, Terrault N, Pazienza V, Giordani MT, Giostra E, Sonzogni A, Ruggiero G, Marcellin P, Powell EE, George J, Negro F: Relationship between steatosis, inflammation, and fibrosis in chronic hepatitis C: a meta-analysis of individual patient data. Gastroenterology 2006;130:16361642

79 Wedemeyer I, Bechmann LP, Odenthal M, Jochum C, Marquitan G, Drebber U, Gerken G, Gieseler RK, Dienes HP, Canbay A: Adiponectin inhibits steatotic CD95/Fas up-regulation by hepatocytes: therapeutic implications for hepatitis C. J Hepatol 2009;50: 140-149.

80 Cheung O, Sanyal AJ: Hepatitis C infection and nonalcoholic fatty liver disease. Clin Liver Dis 2008;12:573-585, viii-ix.

81 Lam NP, Pitrak D, Speralakis R, Lau AH, Wiley TE, Layden TJ: Effect of obesity on pharmacokinetics and biologic effect of interferon- $\alpha$ in hepatitis C. Dig Dis Sci 1997; 42:178-185

82 Sheikh MY, Choi J, Qadri I, Friedman JE, Sanyal AJ: Hepatitis C virus infection: molecular pathways to metabolic syndrome. Hepatology 2008;47:2127-2133.

83 Zografos TA, Rigopoulou EI, Liaskos C, Togousidis E, Zachou K, Gatselis N, Germenis A, Dalekos GN: Alterations of leptin during IFN- $\alpha$ therapy in patients with chronic viral hepatitis. J Hepatol 2006;44:848-855.

84 Giannini E, Ceppa P, Botta F, Mastracci L, Romagnoli P, Comino I, Pasini A, Risso D, Lantieri PB, Icardi G, Barreca T, Testa R: Leptin has no role in determining severity of steatosis and fibrosis in patients with chronic hepatitis C. Am J Gastroenterol 2000;95: 3211-3217.

85 Testa R, Franceschini R, Giannini E, Cataldi A, Botta F, Fasoli A, Tenerelli P, Rolandi E, Barreca T: Serum leptin levels in patients with viral chronic hepatitis or liver cirrhosis. J Hepatol 2000;33:33-37.

-86 Crespo J, Rivero M, Fábrega E, Cayón A, Amado JA, García-Unzeta MT, Pons-Romero F: Plasma leptin and $\mathrm{TNF}-\alpha$ levels in chronic hepatitis $\mathrm{C}$ patients and their relationship to hepatic fibrosis. Dig Dis Sci 2002; 47:1604-1610.

$>87$ Piche T, Vandenbos F, Abakar-Mahamat A, Vanbiervliet G, Barjoan EM, Calle G, Giudicelli J, Ferrua B, Laffont C, Benzaken S, Tran A: The severity of liver fibrosis is associated with high leptin levels in chronic hepatitis C. J Viral Hepat 2004;11:91-96.

$>88$ Gordon A, McLean CA, Pedersen JS, Bailey MJ, Roberts SK: Hepatic steatosis in chronic hepatitis B and C: predictors, distribution and effect on fibrosis. J Hepatol 2005;43:38-44.

89 Romero-Gómez M, Castellano-Megias VM, Grande L, Irles JA, Cruz M, Nogales MC, Alcón JC, Robles A: Serum leptin levels correlate with hepatic steatosis in chronic hepatitis C. Am J Gastroenterol 2003;98:1135-1141. 
>90 Liu C, Chen P, Jeng Y, Huang W, Yang W, Lai M, Kao J, Chen D: Serum adiponectin correlates with viral characteristics but not histologic features in patients with chronic hepatitis C. J Hepatol 2005;43:235-242.

-91 Lu J, Chuang L, Yang W, Tai T, Lai M, Chen P, Kao J, Lee C, Lee H: Adiponectin levels among patients with chronic hepatitis $\mathrm{B}$ and $\mathrm{C}$ infections and in response to IFN- $\alpha$ therapy. Liver Int 2005;25:752-759.

$\checkmark 92$ Sato S, Furuta K, Mishiro T, Miyake T, Kohge N, Akagi S, Adachi K, Kinoshita Y: Serum adiponectin concentration in patients with hepatitis C virus. J Clin Gastroenterol 2005; 39:744-745.

-93 Cua IHY, Hui JM, Bandara P, Kench JG, Farrell GC, McCaughan GW, George J: Insulin resistance and liver injury in hepatitis $\mathrm{C}$ is not associated with virus-specific changes in adipocytokines. Hepatology 2007;46:66-73.

-94 Petit J, Minello A, Jooste V, Bour JB, Galland F, Duvillard L, Verges B, Olsson NO, Gambert P, Hillon P: Decreased plasma adiponectin concentrations are closely related to steatosis in hepatitis $\mathrm{C}$ virus-infected patients. J Clin Endocrinol Metab 2005;90:22402243.
95 Jonsson JR, Moschen AR, Hickman IJ, Richardson MM, Kaser S, Clouston AD, Powell EE, Tilg H: Adiponectin and its receptors in patients with chronic hepatitis C. J Hepatol 2005;43:929-936.

96 Durante-Mangoni E, Zampino R, Marrone A, Tripodi M, Rinaldi L, Restivo L, Cioffi M, Ruggiero G, Adinolfi LE: Hepatic steatosis and insulin resistance are associated with serum imbalance of adiponectin/tumour necrosis factor- $\alpha$ in chronic hepatitis $\mathrm{C}$ patients. Aliment Pharmacol Ther 2006;24: 1349-1357.

97 Wang AY, Hickman IJ, Richards AA, Whitehead JP, Prins JB, Macdonald GA: High molecular weight adiponectin correlates with insulin sensitivity in patients with hepatitis C genotype 3, but not genotype 1 infection. Am J Gastroenterol 2005;100:2717-2723.

98 Zografos TA, Liaskos C, Rigopoulou EI, Togousidis E, Makaritsis $\mathrm{K}$, Germenis A, Dalekos GN: Adiponectin: a new independent predictor of liver steatosis and response to IFN- $\alpha$ treatment in chronic hepatitis C. Am J Gastroenterol 2008;103:605-614.

99 Tsochatzis E, Papatheodoridis GV, Hadziyannis E, Georgiou A, Kafiri G, Tiniakos DG, Manesis EK, Archimandritis AJ: Serum adipokine levels in chronic liver diseases: association of resistin levels with fibrosis severity. Scand J Gastroenterol 2008;43:11281136.
100 O’Grady JG: Acute liver failure. Postgrad Med J 2005;81:148-154.

101 Canbay A, Chen S, Gieseler RK, Malago M, Karliova M, Gerken G, Broelsch CE, Treichel U: Overweight patients are more susceptible for acute liver failure. Hepatogastroenterology 2005;52:1516-1520.

102 Rutherford A, Davern T, Hay JE, Murray NG, Hassanein T, Lee WM, Chung RT: Influence of high body mass index on outcome in acute liver failure. Clin Gastroenterol Hepatol 2006;4:1544-1549.

103 Canbay A, Jochum C, Bechmann LP, Festag S, Gieseler RK, Yüksel Z, Lütkes P, Saner FH, Paul A, Gerken G: Acute liver failure in a metropolitan area in Germany: a retrospective study (2002-2008). Z Gastroenterol 2009;47:807-813.

104 Feldstein AE, Canbay A, Guicciardi ME, Higuchi H, Bronk SF, Gores GJ: Diet-associated hepatic steatosis sensitizes to Fasmediated liver injury in mice. J Hepatol 2003;39:978-983. 